\title{
AVALIAĈ̃O DO PROJETO DE VALORIZACCÃO DE NASCENTES URBANAS NA BACIA HIDROGRÁFICA DO RIBEIRÃO DO ONÇA: O IMPACTO NA PERCEPÇÃO SOCIAL DE DUAS NASCENTES
}

\author{
Natalia Duarte Cáceres \\ Universidade Federal de Minas Gerais, Instituto de Geociências, Pós-Graduação em Geografia, \\ Belo Horizonte, MG, Brasil \\ duarte.caceres.natalia@gmail.com \\ Brenner Henrique Maia Rodrigues \\ Universidade Federal de Minas Gerais, Instituto de Geociências, Pós-Graduação em Geografia, \\ Belo Horizonte, MG, Brasil \\ bhmrodrigues@gmail.com \\ Letícia Augusta Faria de Oliveira \\ Universidade Federal de Minas Gerais, Instituto de Geociências, Pós-Graduação em Geografia, \\ Belo Horizonte, MG, Brasil \\ leticia.afoliveira@gmail.com \\ Antônio Pereira Magalhães Jr. \\ Universidade Federal de Minas Gerais, Instituto de Geociências, Belo Horizonte, MG, Brasil \\ antonio.magalhaes.ufmg@gmail.com
}

\begin{abstract}
RESUMO
A efetividade das medidas de valorização e de restauração ambiental de qualquer bacia hidrográfica depende, principalmente, da boa receptividade por parte da população local e do impacto das medidas em termos de transformações do comportamento e sensibilização ambiental. $O$ presente artigo apresenta os resultados de uma pesquisa qualitativa que avaliou a apropriação social das intervenções físicas e paisagísticas efetuadas em duas das nove nascentes compreendidas na segunda etapa do projeto "Valorização de nascentes urbanas na bacia do ribeirão do Onça", o qual foi formulado e desenvolvido pelo Subcomitê da bacia hidrográfica do Onça (Região Metropolitana de Belo Horizonte-MG) com recursos advindos da cobrança pelo uso da água. Quatro ferramentas metodológicas - a observação direta, as entrevistas semi-estruturadas, os questionários e as cartografias sociais permitiram concluir que as medidas executadas conseguiram incrementar a visibilidade das nascentes, bem como promover uma percepção mais positiva sobre as áreas onde as mesmas encontram-se inseridas. No entanto, identificou-se que existe um vazio pedagógico no projeto, pois a valorização da área das nascentes por parte das comunidades não acarretou uma maior compreensão sobre a importância desses sistemas para a manutenção da qualidade ambiental das bacias hidrográficas.
\end{abstract}

Palavras-chave: Nascentes urbanas. Restauração ambiental. Educação ambiental. Apropriação social.

\section{EVALUACIÓN DEL PROYECTO DE VALORIZACIÓN DE NACIMIENTOS URBANOS EN LA CUENCA HIDROGRÁFICA DEL RÍO ONCCA: EL IMPACTO EN LA PERCEPCIÓN SOCIAL DE DOS NACIMIENTOS}

\section{RESUMEN}

La efectividad de las medidas de valorización y restauración ambiental de cualquier cuenca hidrográfica depende, principalmente, de la buena receptividad por parte de la población local, así como del impacto de éstas en términos de transformación del comportamiento y sensibilización ambiental. Este artículo presenta los resultados de una investigación cualitativa que evaluó la apropiación social de las intervenciones efectuadas en dos 
nacimientos de los nueve comprehendidos por la segunda parte del proyecto "Valorización de los nacimientos urbanos en la cuenca del río Onça", el cual fue formulado y desarrollado por el Subcomité de la cuenca hidrográfica del río Onça (Región Metropolitana de Belo Horizonte, Brasil) con recursos provenientes del cobro por el uso del agua. Cuatro herramientas metodológicas -observación directa, entrevistas semidirigidas, cuestionarios y cartografías sociales - permitieron concluir que las medidas ejecutadas incrementaron la visibilidad de los nacimientos y promovieron una percepción más positiva sobre el área donde éstos se encuentran localizados. Empero, se identificó un vacío pedagógico en el proyecto en la medida en que la valorización de dicha área por parte de la comunidad no acarreó una mayor comprensión sobre la importancia que poseen estos sistemas hídricos para la protección de la calidad ambiental de las cuencas hidrográficas.

Palabras clave: Nacientes urbanas. Restauración ambiental. Educación ambiental. Apropiación social.

\title{
INTRODUÇÃO
}

A Política Nacional de Recursos Hídricos (PNRH), instituída através da lei 9.433 de 1997, previu mecanismos e métodos para a gestão de águas no Brasil. Um desses mecanismos é a criação dos Comitês de Bacias Hidrográficas, instâncias consultivas e deliberativas que buscam descentralizar e democratizar a gestão de recursos hídricos, assegurando a participação da sociedade civil, do poder público e de grandes usuários de águas nos processos decisórios (BRASIL, 1997). Dentro desse contexto, o Comitê de Bacia Hidrográfica do rio das Velhas (CBH rio das Velhas), instituído pelo Decreto Estadual 39.692 de 29 de junho de 1998 (MINAS GERAIS, 1998), foi um dos primeiros a ser constituído no país.

Como parte de uma estratégia de fomento à participação de atores locais nos processos de tomada de decisões e de gestão da bacia, o $\mathrm{CBH}$ rio das Velhas promoveu a descentralização de sua estrutura por meio da criação dos Subcomitês de Bacia Hidrográfica (SCBH), a partir da Deliberação Normativa $n^{\circ} .2$ de 31 de agosto de 2004 (CBH VELHAS, 2004). Os subcomitês são colegiados consultivos e propositivos, possuindo como competências:

\begin{abstract}
"Acompanhar a elaboração e implementação do Plano de Recursos Hídricos da bacia hidrográfica do rio das Velhas em sua área de atuação, prioritariamente no que diz respeito às atividades de preservação, conservação e recuperação hidroambiental da bacia, formulando sugestões ao CBH-Velhas para o cumprimento de seus objetivos e para suas atualizações" (Art. 3, CBH VELHAS, 2004).
\end{abstract}

A criação dos subcomitês buscou ampliar o espaço de participação dos diferentes setores da sociedade, bem como garantir que as propostas contidas no Plano Diretor da bacia do rio das Velhas e os projetos executados com os recursos advindos da cobrança pelo uso da água, se adequem melhor às heterogeneidades locais (SEPÚLVEDA, 2006). Os Subcomitês de Bacia Hidrográfica dos ribeirões do Onça e Arrudas são produtos dessa estratégia de descentralização e mobilização social, exercendo hoje um importante papel de articuladores das lideranças e entidades públicas que desenvolvem atividades relacionadas às questões ambientais, sociais e educacionais no nível local.

Um exemplo do trabalho em conjunto do $\mathrm{CBH}$ Velhas com os SCBH é o projeto de "Valorização das nascentes urbanas nas bacias hidrográficas dos ribeirões Arrudas e do Onça", iniciado em 2010 como resposta às demandas dos SCBH dos ribeirões do Onça e Arrudas. Como resultado dessa iniciativa, 345 nascentes foram cadastradas, 162 na bacia do ribeirão do Onça e 183 na bacia do ribeirão Arrudas, tendo sido identificados, também, os cuidadores da maior parte delas. Além disso, o projeto propôs planos de ação para a recuperação de 60 nascentes (30 em cada bacia) consideradas prioritárias pelos membros dos subcomitês (SCBH ONÇA, 2016).

Em 2016, numa segunda etapa do projeto, esses dois subcomitês, por meio da agência de bacia Peixe Vivo, realizaram a contratação de empresas para a execução de intervenções paisagísticas, de conservação, mobilização e educação ambiental em 16 das nascentes, 9 no ribeirão do Onça e 7 no ribeirão Arrudas (SCBH ONÇA, 2016). A seleção destas nascentes foi produto de metodologias participativas desenvolvidas com os membros dos subcomitês, bem como das opiniões recolhidas em visitas de campo realizadas nas duas áreas das bacias.

Dada a complexidade desse processo de seleção, as iniciativas de intervenção ambiental e de mobilização social, formuladas e promovidas pelos SCBH, devem ser analisadas por meio de uma

$\begin{array}{llllll}\text { Caminhos de Geografia } & \text { Uberlândia - MG } & \text { v. 19, n. } 67 & \text { Set/2018 } & \text { p. 38-53 } & \text { Página } 39\end{array}$


perspectiva ampla, avaliando não só os resultados gerados do ponto de vista físico-estrutural, mas também pedagógico e social. Esse segundo aspecto é, precisamente, o objetivo do presente trabalho, o qual pretendeu avaliar a apropriação social das intervenções físicas e paisagísticas propostas no projeto de valorização de nascentes urbanas na bacia do ribeirão do Onça (Região Metropolitana de Belo Horizonte) a partir da percepção de diferentes atores da sociedade civil.

O termo apropriação social possui várias acepções relacionadas com a percepção e as relações sociais produzidas pelo uso de um espaço físico determinado, isto é, com "as práticas cotidianas que conformam o plano do vivido e que constroem a identidade e o sentimento de pertencimento das pessoas" (SOBARZO, 2006, p. 103). Desse modo, a presente pesquisa buscou analisar variáveis tais como o impacto pedagógico e de sensibilização ambiental do projeto, as reações da população frente às intervenções realizadas e, inclusive, a relação (ou não-relação) das comunidades com os córregos localizados no entorno.

A decisão de focar o trabalho na apropriação social das iniciativas do projeto de valorização de nascentes urbanas se deve a importância do envolvimento das comunidades vizinhas na manutenção e cuidado, não só das nascentes, mas das próprias intervenções. De fato, a efetividade das medidas de valorização e de requalificação ambiental depende, principalmente, da boa receptividade por parte da população local e do impacto dessas medidas em termos de transformações do comportamento e sensibilização ambiental.

\section{METODOLOGIA}

Dado o escopo da presente pesquisa, optou-se por utilizar uma metodologia qualitativa que permitisse abordar as subjetividades e múltiplas visões locais a respeito das intervenções executadas nas nascentes da bacia hidrográfica do ribeirão do Onça. Para tanto, foram selecionadas duas nascentes: a nascente Fundamental do Parque Ciliar do ribeirão do Onça, situada a 60 metros do conjunto habitacional Ribeiro de Abreu, no bairro do mesmo nome, e a nascente do bairro Jardim Felicidade, localizada junto ao muro da EMJF (Figura 1).

Dois critérios determinaram essa escolha. O primeiro, o caráter público de ambas as nascentes, ou seja, o fato das mesmas estarem localizadas em áreas públicas. Essa opção deu-se em função das especificidades inerentes às nascentes em terrenos privados, cujo acesso e possibilidade de uso estão sujeitos aos interesses dos proprietários, o que limita as análises relacionadas à apropriação da comunidade local. O segundo critério está relacionado às características socioeconômicas locais, aspecto esse mensurado a partir do rendimento médio mensal dos chefes de domicílio dos setores censitários onde se encontram inseridas as nascentes (IBGE, 2010).

$\mathrm{Na}$ Tabela 1 são apresentadas as nascentes que foram objeto de intervenção do projeto de valorização, bem como a situação das mesmas quanto a sua localização e aos rendimentos médios mensais dos chefes de domicílio.

O desenvolvimento do trabalho deu-se inicialmente a partir da aplicação de técnicas de observação direta, as quais permitiram caracterizar as intervenções físicas que foram executadas na área das nascentes, realizando, também, um primeiro diagnóstico das dinâmicas sociais do entorno (TELLIS, 1997; JACCOUD e MAYER, 2008). Essa estratégia de pesquisa também facilitou a identificação dos tipos de uso da água das nascentes, relacionando essa informação com os objetivos estipulados dentro do projeto de valorização.

Posteriormente, foram aplicadas 12 entrevistas semi-estruturadas com algumas lideranças e habitantes de ambos os bairros, visando avaliar a receptividade da comunidade local ante as intervenções executadas. Através das entrevistas, procurou-se captar as percepções sociais a respeito da área das duas nascentes, analisando como as intervenções efetuadas influenciaram, ou não, esse sistema de percepções (DAVIDOFF, 1993; MERLEAU-PONTY, 1999). Desse modo, cinco entrevistas foram aplicadas no bairro Ribeiro de Abreu e sete no bairro Jardim Felicidade, interpretando a vivência intersubjetiva das pessoas e as possíveis relações das mesmas com o território (SCHUTZ, 1974, apud, LELO e CAMINHAS, 2013, P.76). 
Figura 1: Mapa de localização das nascentes na bacia do ribeirão do Onça

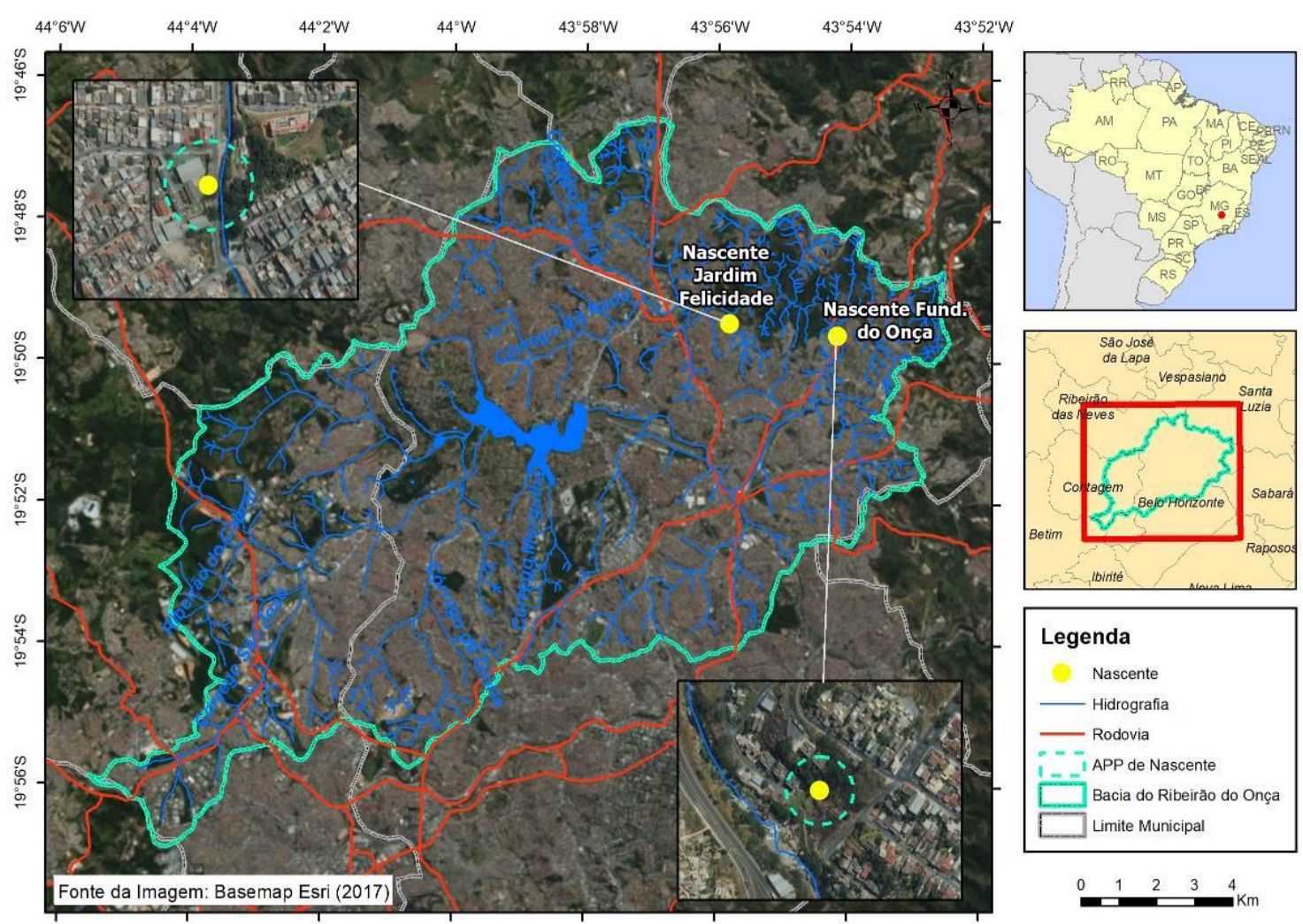

Org.: Autores.

Tabela 1. Características das nove nascentes que sofreram intervenção

\begin{tabular}{lcc}
\hline \multicolumn{1}{c}{ Nome da Nascente } & Localização & Renda Média \\
\hline Quilombo & Particular & $\mathrm{R} \$ 696,84$ \\
Dona Marta & Particular & $\mathrm{R} \$ 1.288,73$ \\
Dona Maria & Particular & $\mathrm{R} \$ 1.052,89$ \\
Nascente das Irmãs & Particular & $\mathrm{R} \$ 4.357,94$ \\
Nascente do Agnaldo & Particular & $\mathrm{R} \$ 1.259,94$ \\
Nascente do bairro Jardim Felicidade & Pública & $\mathrm{R} \$ 1.009,79$ \\
Nascente do Brejinho & Pública & $\mathrm{R} \$ 2.475,13$ \\
Nascente Fundamental do baixo Onça & Pública & $\mathrm{R} \$ 405,00$ \\
Nascente Parque do Planalto & Pública & $\mathrm{R} \$ 3.937,82$ \\
\hline
\end{tabular}

Fonte: Elaboração a partir de IBGE (2010) e SCBH ONÇA, (2016).

Adicionalmente, foram aplicados 20 questionários cujo objetivo principal era captar o impacto do projeto em termos de educação ambiental, no geral, e mudanças no comportamento e na percepção da comunidade sobre as nascentes, em particular. Entre alguns dos aspectos avaliados no questionário, numa escala de um (péssimo) a cinco (excelente), estavam incluídas: a satisfação da comunidade a respeito das intervenções, a participação da mesma na proteção das nascentes antes e após as 
intervenções físicas e as atividades de mobilização social, a compreensão dos habitantes sobre a importância desses sistemas hídricos e a motivação da comunidade para propor projetos de proteção ambiental, entre outros.

Os questionários, compostos por 15 perguntas, foram aplicados em dois contextos diferentes. No bairro Jardim Felicidade, foram respondidos por 12 membros presentes no encontro mensal da Rede de Apoio ao Desenvolvimento do Jardim Felicidade (REDE), uma associação que reúne moradores e representantes de instituições públicas e organizações comunitárias. No bairro Ribeiro de Abreu, os questionários foram respondidos por oito participantes do $8^{\circ}$ Deixem o Onça Beber Água Limpa, um movimento de educação ambiental e mobilização social promovido pelo Conselho Comunitário Unidos pelo Ribeiro de Abreu (COMUPRA).

Finalmente, esses resultados foram complementados com as análises obtidas a partir das cartografias sociais realizadas junto aos alunos da Escola Municipal do Jardim Felicidade (EMJF) e da Escola Municipal Secretário Humberto Almeida (EMSHA), no bairro Ribeiro de Abreu. As cartografias sociais consistem no desenho de uma determinada área por parte de representantes de uma comunidade, os quais conhecem ou habitam na mesma (LIEBMAN e PAULSTON, 1994; PAULSTON, 1996; ACSELRAD, 2004). Esta metodologia participativa de pesquisa é comumente empregada para identificar conflitos socioambientais num território, bem como para captar as visões, percepções e desejos de um grupo populacional a respeito de um espaço físico específico. Nesse sentido,

\begin{abstract}
"Em vez de informações técnicas, o mapa social apresenta o cotidiano de uma comunidade. No mapa são colocados localidades, rios, lagos, cemitérios, casas, igarapés, grotas - independentemente de seu tamanho ou condição. Mapeia-se também mobilizações sociais, descrevendo-as e georreferenciando-as com base no que é considerado relevante pelas próprias comunidades estudadas" (ACSELRAD e COLI, 2008, p.16).
\end{abstract}

Dentro dessa perspectiva, foram selecionados 43 alunos na faixa etária dos 12 aos 15 anos, 18 alunos da EMSHA e 25 alunos da EMJF. Eles foram divididos em três grupos, cada qual tendo que realizar duas cartografias sociais para representar o cenário atual da área das nascentes (primeira cartografia) e os sonhos e desejos relacionados com a mesma (segunda cartografia). Na primeira cartografia, pediu-se para os estudantes retratarem a área exatamente da maneira como eles a percebem: "O que está presente nessa área (água, animais, objetos)? Vocês gostam do lugar?” Na segunda cartografia, perguntou-se aos alunos como eles gostariam que essa área fosse no futuro e quais mudanças gostariam que fossem realizadas nesse espaço físico. Assim, ao analisar e comparar os desenhos, pode-se identificar, por exemplo, quais as intervenções melhor avaliadas e que geram maior interesse, quais os pontos com maior visibilidade e que tipo de problemas, falhas e ameaças se encontram presentes no local onde estão inseridas as nascentes.

\title{
CARACTERIZAÇÃO DAS INTERVENÇÕES
}

As intervenções físicas e paisagísticas propostas no projeto de valorização foram formuladas e realizadas de acordo com o contexto e as necessidades de cada uma das nascentes. No entanto, o objetivo geral das intervenções aqui estudadas focou-se na "qualificação ambiental e valorização do entorno das nascentes, ao promover melhorias paisagísticas que favorecessem a socialização e a consequente preservação do local" (SCBH ONÇA, 2016). Durante a execução dos trabalhos, manteve-se um diálogo constante com os cuidadores das nascentes e as organizações comunitárias de cada área, buscando adaptar as iniciativas às demandas locais.

Na nascente Fundamental do Parque Ciliar do ribeirão do Onça (daqui em diante nascente Fundamental), as medidas e ações de valorização tiveram início em 24 de outubro de 2016 e foram finalizadas no dia 15 de dezembro do mesmo ano, período durante o qual houve grande envolvimento de alguns membros do COMUPRA e do Movimento Deixem o Onça Beber Água Limpa. Em 30 de novembro de 2016, na área do entorno da nascente, realizou-se o evento de inauguração das intervenções, cuja duração foi de oito horas e contou com a participação de cerca de 150 pessoas, dentre as quais se destacam os cuidadores das nascentes, mobilizadores, moradores locais, professores, estudantes, gestores públicos, representantes do CBH Velhas e Subcomitê do Onça, representantes da COPASA, do COMUPRA e das secretarias de meio ambiente de Belo Horizonte e Contagem (SCBH ONÇA, 2017). Neste evento, houve apresentação do projeto, visita guiada à nascente e circuito pedagógico, banda de percussão e hip hop de grupos das escolas mobilizadas da região, além de mensagens criadas em cartazes, músicas, poesias, recados e outras ações, como doações de mudas pelos alunos das escolas.

$\begin{array}{llllll}\text { Caminhos de Geografia } & \text { Uberlândia - MG } & \text { v. 19, n. 67 } & \text { Set/2018 } & \text { p. 38-53 } & \text { Página }\end{array}$


Inicialmente, conforme descrito por SCBH Onça (2016), estava planejado o plantio de espécies florestais nativas, a limpeza da área e a melhoria do acesso à nascente. Porém, a partir da demanda do SCBH ribeirão do Onça e da comunidade local (através do COMUPRA), foram realizadas adequações no projeto. Deste modo, houve a construção de um deck de madeira para evitar o pisoteio da nascente, estrutura essa que atualmente é utilizada para a contemplação da mesma e como local de convívio da comunidade, que, por vezes, realiza piqueniques e atividades escolares (Figuras 2 e 3 ).

Figura 2: Área da nascente Fundamental antes das intervenções

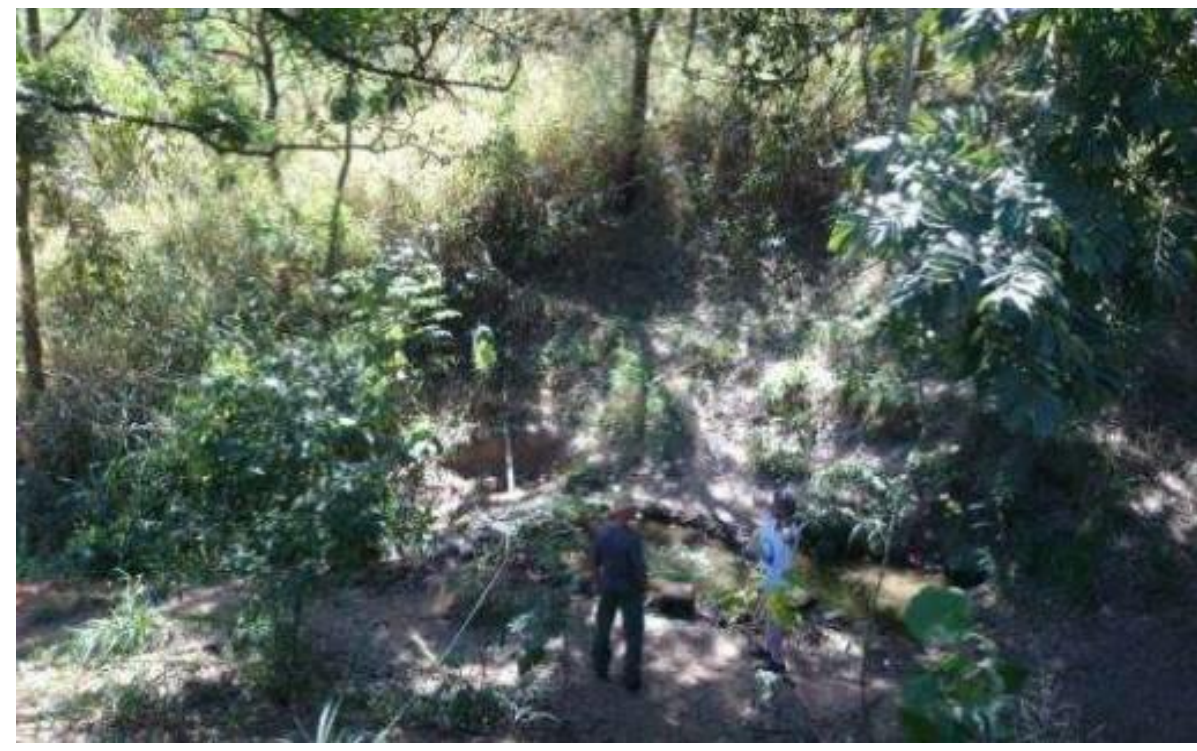

Fonte: SCBH Onça (2017)

Figura 3: Área da nascente Fundamental após as intervenções

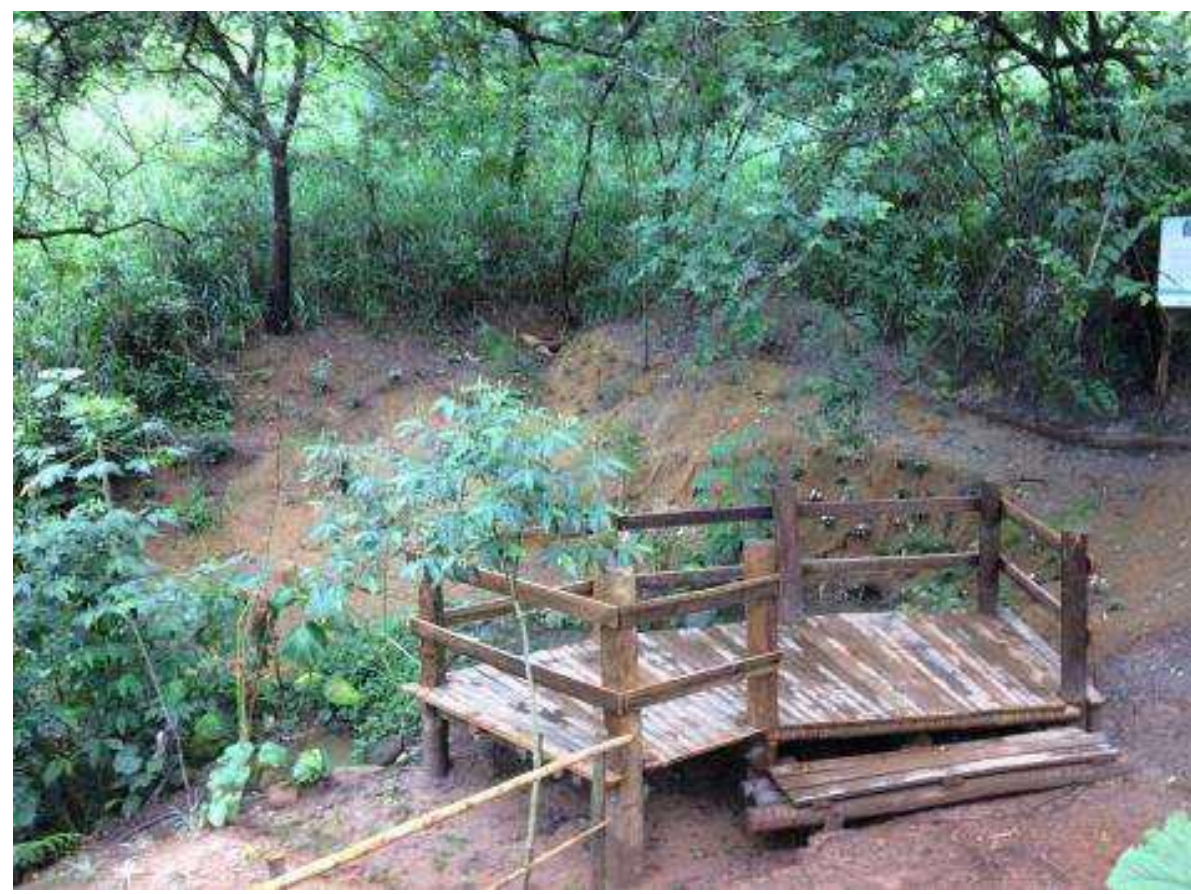

Fonte: SCBH Onça (2017) 
O acesso à nascente foi facilitado pela construção da escadaria com corrimão feito de bambu. Ocorreu, também, o plantio de mudas ornamentais e nativas, tanto próximas à nascente, quanto na planície do ribeirão do Onça e nas proximidades da escadaria que dá acesso à nascente. Além da finalidade paisagística, essa medida contribui para a caracterização do ambiente como um local preservado. Em termos de intervenções estruturais para controle de processos erosivos, houve a instalação de biomantas e retentores de sedimentos. Também foram construídos swales revegetados para contenção das enxurradas (SCBH ONÇA, 2017).

Já na nascente do bairro Jardim Felicidade, nomeada pelos representantes da comunidade como nascente da Felicidade, as intervenções tiveram início em 20 de fevereiro de 2017 e foram finalizadas no dia 3 de março do mesmo ano. $O$ evento de lançamento das intervenções foi realizado em 25 de março de 2017, na EMJF. Dessa inauguração, participaram cerca de 200 pessoas, dentre as quais se destacam os cuidadores das nascentes, mobilizadores, moradores locais, gestores públicos, representantes da AGB Peixe Vivo, do CBH Velhas e do Subcomitê do Onça, representantes da Secretaria de educação de Belo Horizonte, representantes do projeto Manuelzão e, por último, alunos e professores da Faculdade de Arquitetura da UFMG, que apoiaram a parte técnica da intervenção na nascente (SCBH ONÇA, 2017). Durante a inauguração, houve visita ao local e desenho de um grafite temático no muro próximo a nascente, realizado junto aos alunos da EMJF.

Anteriormente, e segundo SCBH Onça (2017), a área encontrava-se descuidada, sendo comuns o consumo de drogas e o despejo de lixo e entulho no local. A água, que exfiltrava da vertente por meio de um cano, era armazenada em duas caixas d'água tendo, como uso comum, ainda hoje, a lavagem de carros (Figura 4). Dessa maneira, as intervenções tiveram como objetivo principal a restauração física e visual, bem como a proteção e cuidado, não só da nascente, mas, também, da área onde ela encontra-se inserida.

Figura 4: Área da nascente do Jardim Felicidade antes das intervenções

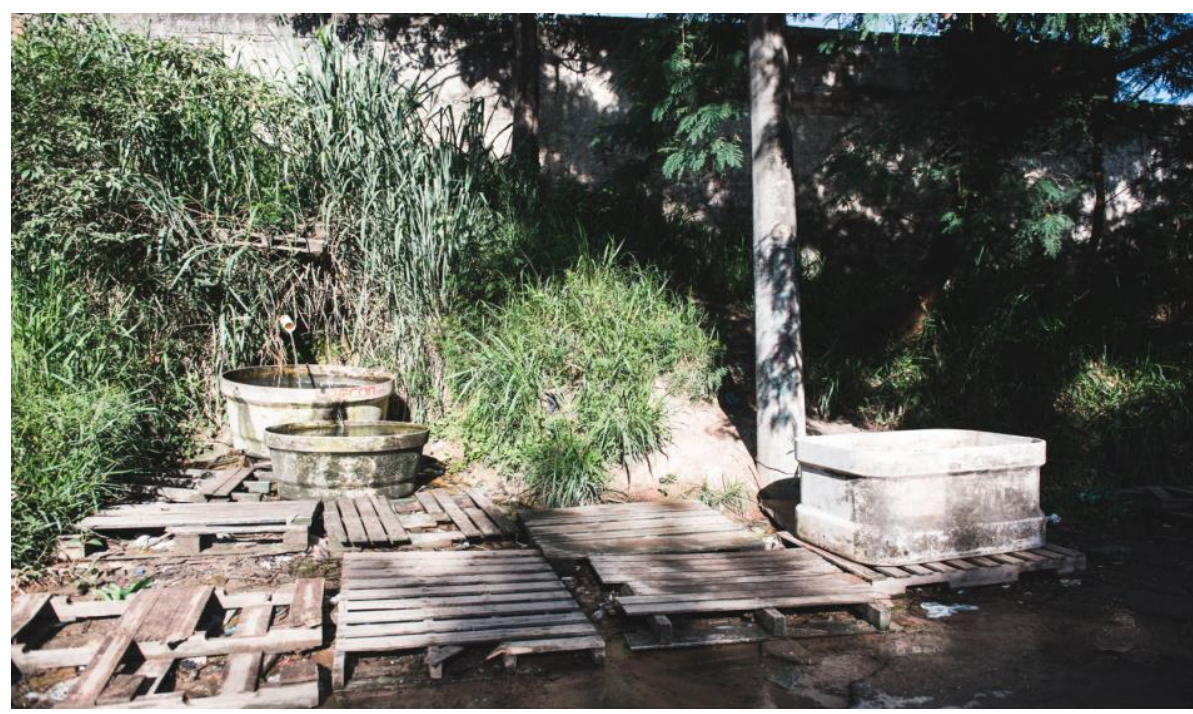

Fonte: SCBH Onça (2017)

Para tanto, as caixas d'água foram substituídas por reservatórios construídos e recobertos por cascalhos claros, foi feita a limpeza da área e realizado o plantio de grama, de árvores nativas e de mudas ornamentais (Figura 5). Além disso, houve a construção de estrutura de contenção da vertente na qual se localiza a bica da nascente, propensa à ocorrência de processos erosivos acelerados. 
Figura 5: Área da nascente do Jardim Felicidade após as intervenções

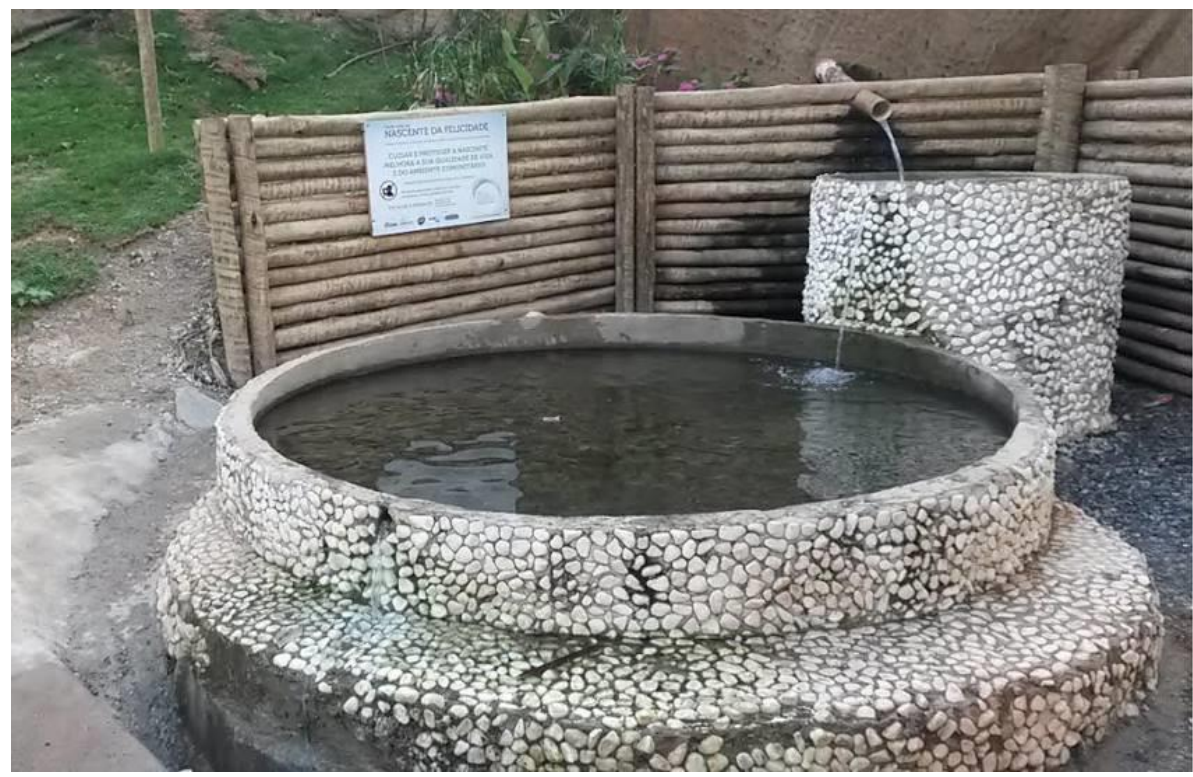

Fonte: Acervo pessoal

\section{OS IMPACTOS NA PERCEPÇÃO DA COMUNIDADE E O GANHO DE VISIBILIDADE DAS NASCENTES}

As atitudes das pessoas a respeito de um lugar determinado dependem, entre outras variáveis, da percepção social e do valor atribuído ao mesmo. O termo "percepção" faz referência não só ao reconhecimento de uma pessoa/objeto/espaço através dos sentidos (MARIN, 2008), mas, também, à intuição e aos imaginários criados a partir de estímulos ambientais, os quais se refletem, muitas vezes, em padrões de comportamento (BESTETTI, 2014). Por isto, os projetos de revitalização ou valorização de qualquer tipo de espaço público (sejam parques, ruas, praças, etc.) focam boa parte dos seus esforços nas transformações dos imaginários, das representações sociais e das maneiras de entender e conceber esse espaço. Ao promover a mudança da percepção social sobre um espaço físico através de intervenções físicas e paisagísticas, como as aqui estudadas, pretende-se gerar um novo tipo de sentimentos, ideais e, sobretudo, de relações com e nesse lugar.

Sob esta ótica, o projeto de valorização de nascentes urbanas teve um impacto significativo, conseguindo gerar uma maior visibilidade das mesmas dentro das comunidades, bem como uma percepção mais positiva sobre as áreas onde estão inseridas. De acordo com as respostas obtidas nos questionários e nas entrevistas semi-estruturadas, as comunidades de ambos os bairros ficaram satisfeitas com as intervenções físicas realizadas, as quais converteram a área das nascentes em espaços propícios para iniciativas de educação ambiental.

Por exemplo, segundo uma professora da EMSHA (bairro Ribeiro de Abreu), o projeto de valorização deu maior visibilidade à nascente Fundamental, fazendo com que as escolas do bairro começassem a participar e desenvolver atividades de sensibilização ambiental, tais como as caminhadas ecológicas:

"Eu descobri a nascente há pouco tempo e eu fui moradora do conjunto que fica do lado da área da nascente. As pessoas, as crianças, não conheciam a nascente antes do projeto. Mas agora a maioria das crianças já a conhece. Nós organizamos caminhadas até lá, pois, se as crianças aprenderem direitinho, elas vão ensinar os pais delas" (entrevista realizada em 10/05/2017).

O incremento na visibilidade e a percepção positiva da comunidade sobre as intervenções executadas podem ser verificadas nas cartografias sociais realizadas pelos alunos dessa escola. Durante a atividade, uma grande parte dos alunos da EMSHA declarou que "o lugar é muito bonito" e, efetivamente, a maior parte das intervenções encontra-se presente nos desenhos. A escadaria e o deck de madeira são elementos comuns na cartografia do cenário atual e, por vezes, também na do cenário futuro, sugerindo a aprovação dessas intervenções por parte dos alunos. A presença de árvores nos arredores da nascente 
também é identificada na maior parte das representações do cenário atual, e multiplicada nas do cenário futuro. Os alunos observaram e registraram, ainda, a presença de girinos na nascente e uma quantidade significativa de árvores e flores nos arredores da mesma, o que permite inferir que, na percepção da maioria dos alunos, eles estão diante de um ambiente agradável (Figura 6).

Figura 6: Cartografia social da nascente Fundamental (cenário atual)

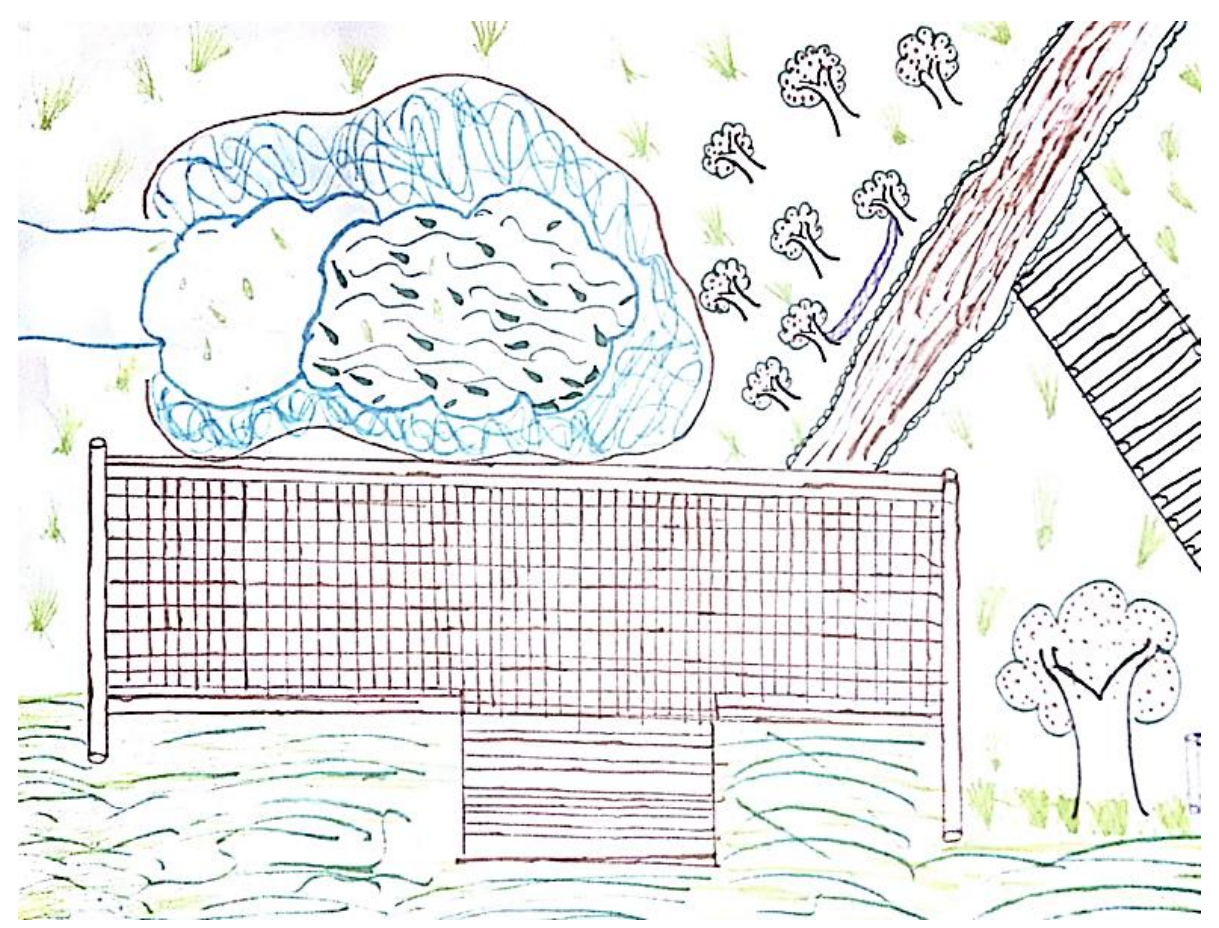

Fonte: Cartografia social realizada junto aos alunos da EMSHA (07/06/2017).

A situação da nascente do Jardim Felicidade difere do caso da nascente Fundamental por estar localizada em um lugar de passagem de carros e pedestres na parte central do bairro, o que a tornou bastante conhecida pela comunidade. De fato, os habitantes do Jardim Felicidade utilizavam - e utilizam - a água da nascente para múltiplas atividades cotidianas, tais como lavar o carro, recreação de contato primário, dar banho nos animais e, em alguns casos, para consumo humano. No entanto, o projeto de valorização fortaleceu e impulsionou as iniciativas ambientais que já existiam e, após as intervenções, foram realizados mutirões para remover o entulho e construir um espaço de lazer no entorno da nascente. Igualmente, e segundo as respostas do questionário, a participação da comunidade no cuidado da nascente foi incrementada após o projeto, talvez porque, como afirmado por um dos membros da REDE, "as pessoas perceberam que é possível realizar mudanças no bairro" (entrevista realizada em dia 10/05/2017).

Este impacto positivo também ficou explícito nas cartografias sociais. Os alunos atribuíram uma grande variedade de cores aos reservatórios - os quais são recobertos de cascalhos claros e de uma só tonalidade - o que aponta que a área é percebida como um lugar limpo, alegre e agradável (Figura $5 \mathrm{e}$ Figura 7). $\mathrm{O}$ fato de reservatórios bastante semelhantes aos atuais terem sido representados nas cartografias sobre cenários futuros - desejos - também corrobora a aprovação dos estudantes para com as intervenções realizadas.

Graças às intervenções, e da mesma maneira como no bairro Ribeiro de Abreu, a nascente do Jardim Felicidade começou a ser utilizada como uma ferramenta para promover a sensibilização ambiental. A EMJF realizou a gravação de uma reportagem na qual os alunos eram os repórteres e, juntamente aos professores, os responsáveis pela elaboração dos textos jornalísticos. Nessa reportagem, foram explicadas várias noções relacionadas com as nascentes, tais como a sua definição e a maneira de

$\begin{array}{llllll}\text { Caminhos de Geografia } & \text { Uberlândia - MG } & \text { v. 19, n. } 67 & \text { Set/2018 } & \text { p. 38-53 } & \text { Página }\end{array}$


monitorar a vazão e a qualidade da água. Os professores e os alunos envolvem-se frequentemente em atividades educativas com foco na nascente, tendo, inclusive, participado da pintura do grafite temático do muro contíguo.

Figura 7. Cartografia social da nascente do Jardim Felicidade (cenário atual)

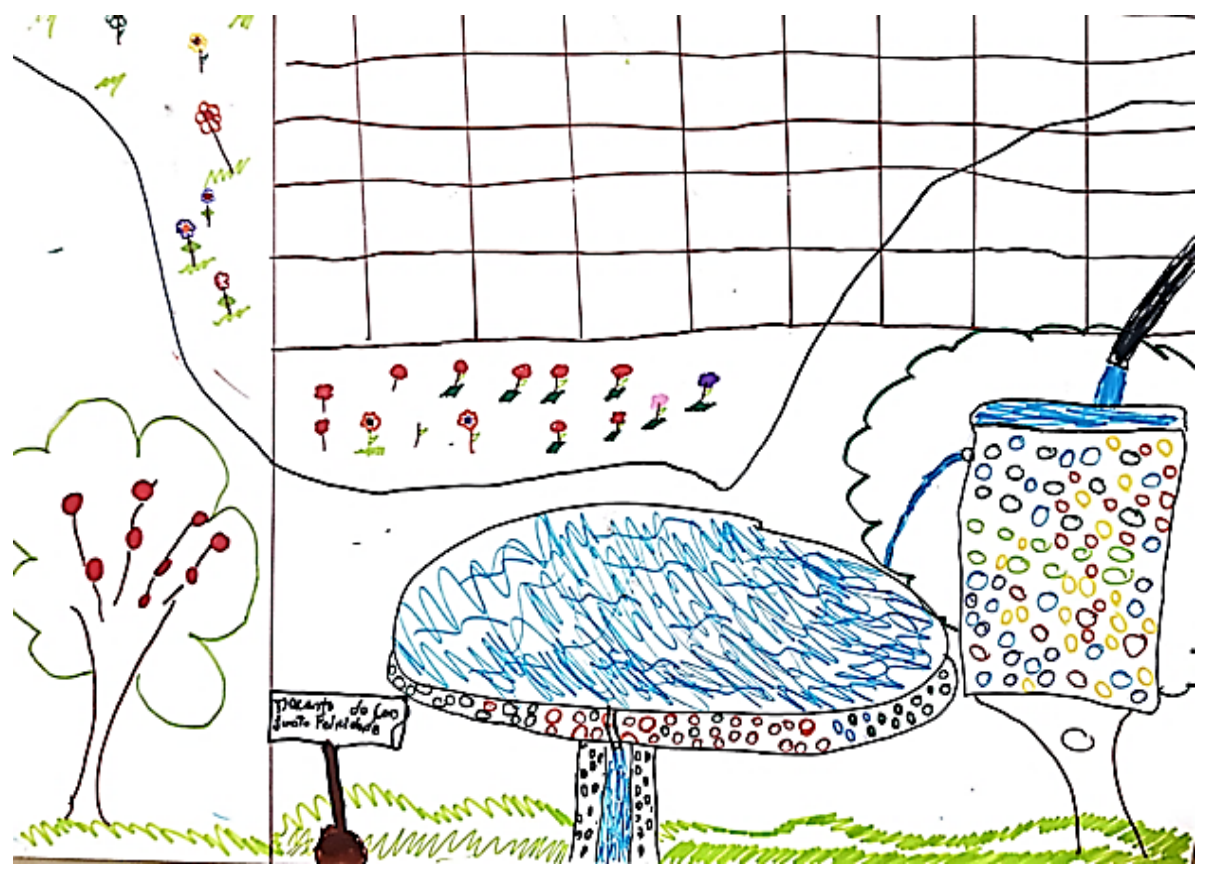

Fonte: Cartografia social realizada junto aos alunos da EMJF (08/06/2017).

Nas cartografias sociais desenvolvidas pelos alunos dessa escola também chama a atenção a presença de alguns elementos que indicam um elevado grau de consciência ambiental adquirida pelos mesmos. Um desses elementos é a ilustração de placa sobreposta ao reservatório contendo a mensagem "Não beber água". Este registro sugere que eles compreenderam a diferença entre água limpa e água potável, pois é comum que os alunos se banhem no reservatório. Percebe-se, portanto, que eles têm o conhecimento de que a água, embora apropriada para recreação de contato primário, não é própria para consumo humano. A ilustração de placas contendo a mensagem "Não jogar lixo", as quais não existem na realidade, tem a mesma relevância.

\section{OS TIPOS DE USO DA ÁGUA DE UMA NASCENTE DETERMINAM A SUA VALORIZAÇÃO?}

Como mencionado, as intervenções físicas e paisagísticas estudadas foram propostas pelos SCBH dos ribeirões do Onça e Arrudas dentro do projeto titulado: "Valorização das Nascentes Urbanas nas Bacias Hidrográficas dos Ribeirões Arrudas e do Onça". Vale ressaltar que o uso do conceito valorização pode ser utilizado em dois sentidos principais. Primeiro, como sinônimo das noções de reabilitação e revitalização, fazendo referência a projetos de restauração ambiental que visam o "restabelecimento de melhores condições para a ocorrência de processos hidrológicos, geomorfológicos e ecológicos em um ambiente degradado, assim como a reposição de componentes danificados do sistema natural" (WOHL et al., 2005, apud, BAPTISTA e CARDOSO, 2013, p.151)

Segundo, a noção de valorização pode ser utilizada no sentido de "dar valor" a algo. Nessa linha, o termo faz alusão à tentativa ou à busca por incrementar o valor que uma sociedade atribui a um objeto ou espaço físico determinado. É sob este ângulo que existe uma diferença significativa nos impactos das intervenções físicas executadas na nascente Fundamental e na nascente do Jardim Felicidade. Apesar 
dessas intervenções terem sido bem avaliadas pelos moradores de ambos os bairros, a valorização da área das nascentes, promovida e gerada pelos projetos, não é a mesma nas duas comunidades.

De acordo com uma professora da EMSHA no bairro Ribeiro de Abreu, a comunidade não aderiu ao projeto e as pessoas começaram a se preocupar com o cuidado da área da nascente Fundamental unicamente por causa do risco de ocupação:

\begin{abstract}
"Tem gente tentando invadir, então a comunidade está mais vigilante só por causa das ocupações [...] A comunidade não engajou, só mudou o comportamento porque agora há um risco maior, o risco das ocupações. Então, agora eles estão se envolvendo porque estão correndo o risco de perder essas áreas" (entrevista realizada em 10/05/2017).
\end{abstract}

Em contraste, uma professora da EMJF, quem também é membro da REDE, declarou que há uma participação significativa da comunidade no cuidado da área da nascente. Igualmente, outro membro da REDE afirmou que os habitantes do bairro valorizam muito a área da nascente, a mesma tendo se convertido, após as intervenções, num importante ponto de encontro e espaço de lazer dentro do bairro. Segundo ele, "houve uma mudança no uso da nascente, passando de um uso meramente utilitário a um espaço de lazer e recriação" (entrevista realizada em 09/05/2017).

Essas declarações são confirmadas no relatório de acompanhamento das intervenções, onde se afirma que "o envolvimento da população merece destaque, tanto pelo histórico de atuação e uso que já estava estabelecido, quanto pela continuidade na participação ao longo dos trabalhos e no apoio ativo ao desenvolvimento das atividades do projeto" (SCBH ONÇA, 2017, p.50).

As diferenças do ponto de vista da valorização da área das nascentes por parte das duas comunidades podem responder a dois fatores principais. O primeiro, independente das intervenções, possui relação com a localização das nascentes. A nascente Fundamental encontra-se situada numa área mais afastada, a 150 metros do asfalto (SCBH ONÇA, 2016). Em contraposição, a nascente do bairro Jardim Felicidade - cuja água escoa diretamente no córrego Tamboril- está localizada no muro da EMJF, o que significa que é um lugar de passagem importante dos pais, crianças e funcionários que fazem parte dessa escola.

O segundo fator está relacionado aos usos da água das nascentes, incentivados e possibilitados pelas intervenções físicas. Na nascente Fundamental, as intervenções parecem ter tido como objetivo a promoção do uso paisagístico da água, com o deck tendo sido construído expressamente "para evitar o pisoteio da nascente" (SCBH ONÇA, 2017). Já no Jardim Felicidade, a construção dos reservatórios parece refletir e respeitar os usos que a comunidade dava à água, inclusive antes das intervenções serem executadas: lavagem de carros, dessedentação dos animais e recreação de contato primário. $\mathrm{O}$ fato dos moradores conseguirem aproveitar e utilizar a água da nascente no seu dia-a-dia pode ser um fator determinante para a valorização da mesma.

Com efeito, quando questionada sobre o cuidado que a comunidade do bairro Jardim Felicidade dava à nascente após as intervenções, uma das pessoas membro da REDE respondeu:

\begin{abstract}
"A comunidade gosta muito da nascente e cuida dela. As pessoas nadam na nascente, dão banho nas crianças. No dia da inauguração, todo mundo entrou na nascente, todo mundo estava dentro (...) É a primeira vez que a gente vê a comunidade junta. Virou um espaço de encontro. É um espaço que não existia no bairro" (entrevista realizada em 09/05/2017).
\end{abstract}

Outro membro da REDE também afirmou que, inicialmente, os moradores estavam muito preocupados com as intervenções que estavam sendo realizadas na nascente, pois eles pensavam que não poderiam continuar lavando os carros nessa área. A análise dos elementos representados nas cartografias sociais indica que o uso ativo das nascentes tem uma significativa relevância na percepção e o valor que as comunidades atribuem às mesmas.

Para entender como os usos se articulam com variáveis tais como a reação da comunidade e a percepção sobre a qualidade ambiental da área (poluição ou água limpa), todos os elementos representados nas cartografias sociais foram contabilizados e categorizados em dez grupos, conforme descrito na Tabela 2.

O percentual de ocorrência dessas categorias nas cartografias da nascente Jardim Felicidade pode ser verificado na Figura 8 . No cenário presente, a maior parte das representações está ligada à presença de vegetação, seguidas por elementos urbanos/antrópicos, nascentes e intervenções físicas do projeto. Já nos cenários futuros, é possível verificar que as principais mudanças ocorridas

$\begin{array}{llllll}\text { Caminhos de Geografia } & \text { Uberlândia - MG } & \text { v. 19, n. } 67 & \text { Set/2018 } & \text { p. 38-53 } & \text { Página }\end{array}$


estão associadas à representação de elementos ligados à vegetação, ao uso e às intervenções físicas do projeto. Embora essa nascente já possua usos diversos, a representação dos elementos relativos a essa categoria aumenta de $7 \%$ para $19 \%$ no cenário futuro, o que indica a relevância do uso no que se refere às formas de apropriação das nascentes.

Tabela 2: Categorização dos elementos representados nas cartografias sociais

\begin{tabular}{|c|c|}
\hline $\begin{array}{l}\text { Categorização dos } \\
\text { elementos }\end{array}$ & Descrição \\
\hline Água limpa & $\begin{array}{l}\text { Categoria na qual são contabilizadas representações de água na cor } \\
\text { azul, indicativas de águas com boa qualidade. }\end{array}$ \\
\hline Animais & $\begin{array}{l}\text { Categoria que inclui representações de pássaros, peixes, borboletas, } \\
\text { garças, girinos e cachorros. }\end{array}$ \\
\hline Elemento urbano/antrópico & $\begin{array}{l}\text { Categoria na qual são contabilizadas representações de estruturas } \\
\text { urbanas como ruas, casas, carros, motos e escolas. }\end{array}$ \\
\hline Intervenção física do projeto & $\begin{array}{l}\text { Categoria que representa as intervenções realizadas como parte do } \\
\text { projeto de valorização das nascentes, tais como contenção de madeira, } \\
\text { deck, escada e placas de identificação do projeto. }\end{array}$ \\
\hline Nascente & Categoria que incorpora representações da nascente. \\
\hline Poluição & Categoria que incorpora representação de água na cor preta e lixo. \\
\hline Rio & $\begin{array}{l}\text { Categoria que contabiliza representações dos rios para os quais drenam } \\
\text { as águas das nascentes, a saber, o ribeirão do Onça e o córrego } \\
\text { Tamboril. }\end{array}$ \\
\hline Uso & $\begin{array}{l}\text { Categoria na qual são contabilizadas representações de usos da água } \\
\text { das nascentes ou dos espaços onde elas se encontram inseridas. Nessa } \\
\text { categoria são incluídos elementos físicos não existentes relativos aos } \\
\text { usos desejados, tais como parquinhos, balanços, campos de futebol e } \\
\text { rodas gigantes que alterariam a forma como a população se relaciona } \\
\text { com os espaços onde as nascentes se encontram localizadas, bem como } \\
\text { usos das águas, tais como pesca, recreação de contato primário e } \\
\text { irrigação de hortas. }\end{array}$ \\
\hline Vegetação & $\begin{array}{l}\text { Categoria que incorpora elementos ligados à vegetação tais como } \\
\text { árvores, árvores frutíferas, flores e gramíneas. }\end{array}$ \\
\hline Outro & $\begin{array}{l}\text { Grupo no qual foram incluídos os demais elementos não associados a } \\
\text { outros grupos, tais como sol, nuvens, lixeira e placas. }\end{array}$ \\
\hline
\end{tabular}

Org.: Autores.

No caso da nascente Fundamental, as cartografias indicam a predominância de elementos ligados às categorias animais, vegetação, intervenções físicas do projeto, poluição e rio (Figura 9). Enquanto no cenário presente não ocorreu nenhum tipo de representação ligada ao uso, no cenário futuro $19 \%$ das representações fazem referência a algum elemento dessa categoria. Verifica-se, tanto a menção ao uso da água, sobretudo de recreação de contato primário, quanto ao uso do espaço onde ela se encontra inserida (parquinhos, balanços e campos de futebol). No tocante à poluição, enquanto $10 \%$ das representações no cenário presente estavam ligadas a essa categoria, no cenário futuro nenhum elemento desse tipo foi inserido nas cartografias. Já no relativo à categoria animais, embora a variação em números absolutos tenha sido pequena nos dois cenários, percentualmente as alterações foram altas em função do aumento do número de elementos representados, a saber, de 29 no cenário presente e de 47 
no cenário futuro. Há que se destacar também que as representações relacionadas às intervenções físicas do projeto continuam representadas no cenário futuro, tal como foi mencionado anteriormente.

Figura 8: Representatividade percentual dos elementos presentes nas cartografias sociais da nascente Jardim Felicidade a partir das categorias propostas.

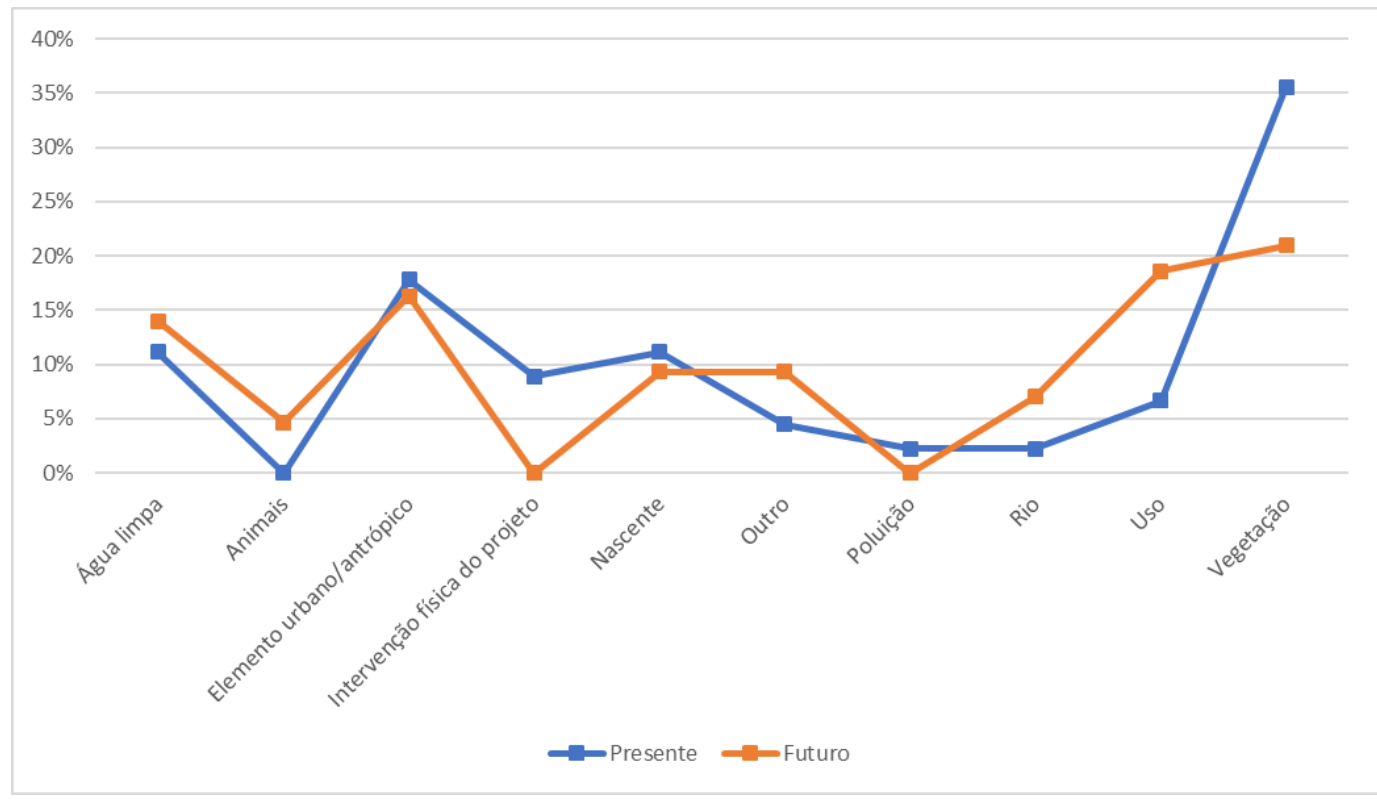

Org.: Autores.

Figura 9: Representatividade percentual dos elementos presentes nas cartografias sociais da nascente Fundamental a partir das categorias propostas.

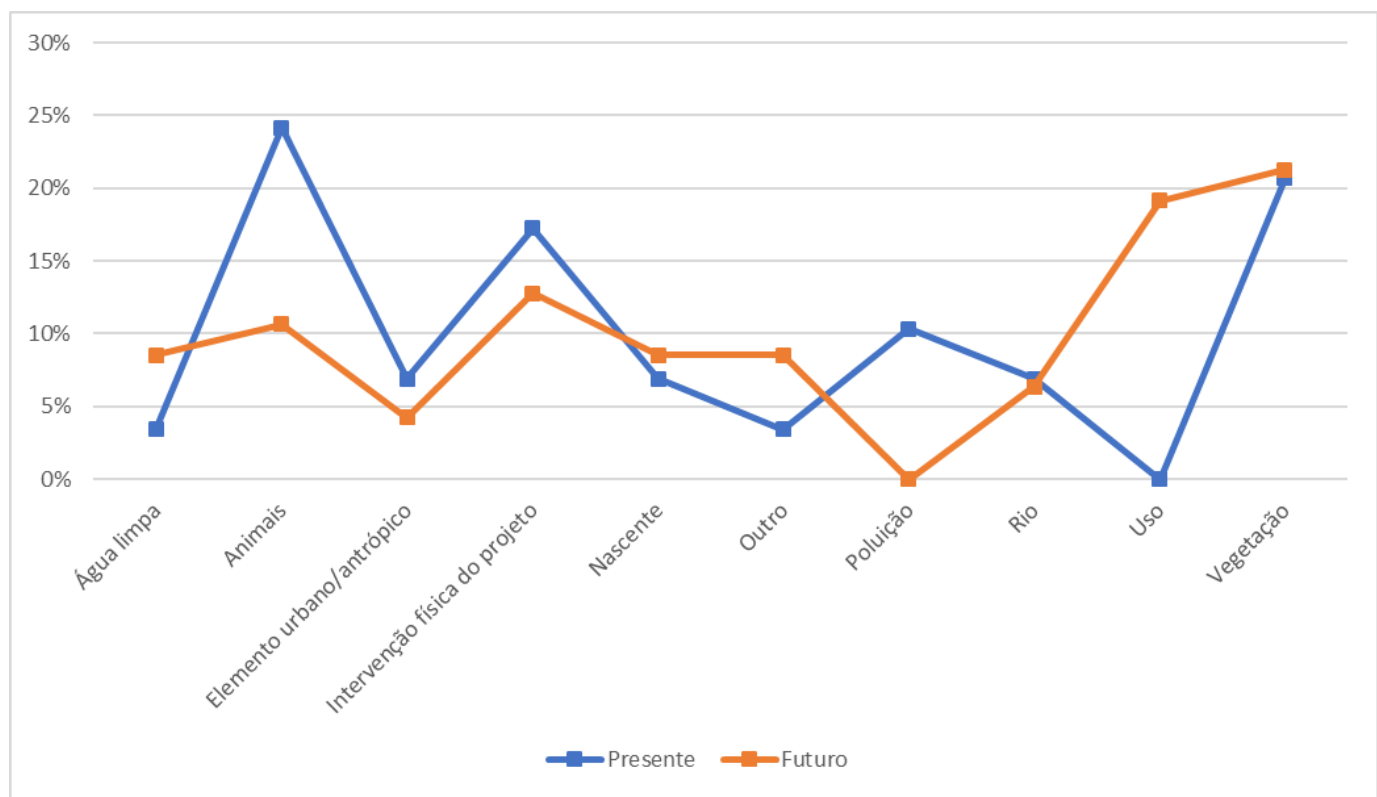

Org.: Autores. 
A análise desses múltiplos elementos indica que a valorização das nascentes por parte das comunidades não está necessariamente relacionada à compreensão que elas têm sobre 0 valor ambiental desse sistema hídrico. Chama a atenção, por exemplo, que os questionários aplicados em ambas as comunidades, bem como as entrevistas e as cartografias sociais, apontam que o ganho de visibilidade da área das nascentes não acarretou a valorização do córrego Tamboril e ribeirão do Onça, situados no entorno das nascentes do Jardim Felicidade e Fundamental, respectivamente. Com efeito, nas cartografias sociais desenhadas pelos alunos da EMJF, verifica-se que o córrego Tamboril foi representado apenas em uma das cartografias do cenário presente - onde aparece desenhado em marrom - o que indica que as crianças percebem o mesmo como um lugar pouco agradável e/ou com uma área altamente poluída. Esse cenário muda nas cartografias do futuro, com $7 \%$ dos elementos fazendo alusão a esse corpo hídrico, o qual é representado com as cores azul e verde. Ademais, durante a atividade, vários alunos fizeram referência à possibilidade de aterrar o córrego. Isto foi constatado por um dos membros da REDE, quem afirmou: "Se a gente perguntar para a comunidade, a maior parte vai falar que tem que tampar o córrego" (entrevista realizada em 13/06/2017).

Portanto, identificou-se que existe um vazio pedagógico no projeto de valorização das nascentes, sendo indispensável reforçar, de maneira mais clara, a importância ambiental que possuem as nascentes devido à sua estreita relação com o território e os cursos de água no entorno. Sem uma compreensão integral das razões que embasam e justificam o investimento nesse tipo de intervenções, o projeto de valorização não acarretará, no longo prazo, a melhoria ambiental da bacia hidrográfica, no geral, ou dos córregos e ribeirões aos quais escoam as águas das nascentes Fundamental e do Jardim Felicidade, em particular.

Cuidar de um corpo d'água é uma noção subjetiva, pois a proteção e a conservação são duas ideias que, sob a ótica da gestão ambiental, contrastam e diferem do que as comunidades entendem por esses dois conceitos. Durante a entrevista com uma pessoa membro da REDE, ela comentou que: "Antes das intervenções, as pessoas da comunidade também cuidavam da nascente, só que do jeito delas. Se você olhar as fotos, dá para pensar que as pessoas não cuidavam do lugar, mas cuidavam sim...". (entrevista realizada em 09/05/2017). O valor atribuído às nascentes parece estar ligado, principalmente, à "utilidade" desse recurso natural e não à sensibilização ambiental da população que mora no entorno.

\section{CONSIDERAÇÕES FINAIS}

A avaliação do projeto "Valorização das Nascentes Urbanas nas Bacias Hidrográficas dos Ribeirões Arrudas e do Onça", promovidas pelos subcomitês respectivos, permitiu identificar que a população dos bairros Ribeiro de Abreu e Jardim Felicidade percebe como positivas as intervenções físicas e paisagísticas realizadas na área das nascentes Fundamental e Felicidade. Graças a essas intervenções, as nascentes ganharam visibilidade dentro da comunidade, transformando-se em cenários propícios para o convívio e a educação ambiental.

Porém, dois desafios deverão ser abordados pelo subcomitê do Onça a fim de atingir o objetivo de valorização, tanto ambiental quanto social, das nascentes urbanas selecionadas. $O$ primeiro deles, 0 envolvimento da comunidade na manutenção e cuidado constante, não só das intervenções realizadas, mas, também, da área das nascentes. Embora ambas as comunidades aprovem as medidas e apreciem o lugar, ainda é necessário ampliar o grupo de pessoas que participam ativamente no cuidado e proteção das nascentes. Em ambos os bairros, as associações comunitárias e as escolas municipais desempenham um papel chave nesse processo ao constituir-se como espaços de divulgação do projeto, bem como de formação, sensibilização e multiplicação do conhecimento ambiental.

O segundo desafio diz respeito à compreensão, por parte da comunidade, das razões ambientais que embasam o projeto de valorização das nascentes, isto é, ao impacto do mesmo, do ponto de vista pedagógico e, finalmente, ambiental. No caso aqui estudado, a maior parte dos moradores aprovaram as intervenções físicas e paisagísticas realizadas, o que não significou, todavia, que eles tivessem entendido o porquê delas.

Analisar os tipos de uso efetivo - mas, também, desejado - que as comunidades dão à água, assim como a maneira como elas entendem o cuidado e a proteção dos corpos hídricos, deve ser um ponto central dos projetos que promovem a valorização ambiental e social dos recursos naturais. No caso das nascentes objetos deste estudo, identificou-se que as intervenções físicas que permitem um uso mais "ativo" da água por parte da população parecem gerar uma maior valorização e apropriação social em comparação com aquelas cujo objetivo é, principalmente, fomentar o uso paisagístico. 
A recuperação dos corpos d'água e as melhorias do ponto de vista ambiental dependem, substancialmente, da adesão significativa por parte das comunidades vizinhas. Por isso, é indispensável "explorar as possibilidades do desenvolvimento de um olhar sobre a questão ambiental que se faça sensível ao papel da diversidade sociocultural e ao conflito entre distintos projetos de apropriação e significação do mundo material" (ACSELRAD, 2004, p.15). As intervenções nos corpos hídricos baseadas na concepção de que para proteger a natureza é necessário afastá-la do homem, podem se mostrar menos eficientes na melhoria e cuidado ambiental das bacias hidrográficas.

Assim, a relação entre o conhecimento que possui uma comunidade a respeito do valor ambiental de um recurso natural e o valor cotidiano que a mesma atribui a esse recurso deve ser estreitada e, portanto, incentivada por quaisquer projetos de restauração ambiental. Para que as medidas de restauração ambiental sejam legítimas e, portanto, efetivas, elas devem abordar as múltiplas formas sociais de entender o cuidado e a proteção ambiental, mas, sobretudo, de perceber e de se apropriar dos recursos naturais.

\section{AGRADECIMENTOS}

Os autores agradecem a Coordenação de Aperfeiçoamento Pessoal de Nível Superior (CAPES) e ao Conselho Nacional de Desenvolvimento Científico e Tecnológico (CNPq) pela concessão da bolsa de doutorado ao primeiro e ao segundo autor deste trabalho, respectivamente.

\section{REFERÊNCIAS}

ACSELRAD, H. As práticas espaciais e o campo dos conflitos ambientais. In: ACSELRAD, H. (Ed.). Conflitos ambientais no Brasil. $1^{\text {a }}$ Edição ed. Rio de Janeiro: Relume Dumará, 2004. p. 13-35.

ACSELRAD, H; COLI, L. Disputas territoriais e disputas cartográficas. In: ACSELRAD, H. (Org.). Cartografias sociais e território. Rio De Janeiro: IPPUR/UFRJ. 2008. p.13-43.

BAPTISTA, M.; CARDOSO, A. Rios e Cidades: uma longa e sinuosa história... Revista da Universidade Federal de Minas Gerais, v. 20, n. 2, p. 124-153, 2013.

BESTETTI, M. L. T. Ambiência: espaço físico e comportamento. Revista Brasileira de Geriatria e Gerontologia, v. 17, n. 3, p. 601-610, 2014. https://doi.org/10.1590/1809-9823.2014.13083

BRASIL. Lei $\mathbf{n}^{\circ}$ 9.433, de 8 de janeiro de 1997. Institui a Política Nacional de Recursos Hídricos, cria o Sistema Nacional de Gerenciamento de Recursos Hídricos, regulamenta o inciso XIX do art. 21 da Constituição Federal, e altera o art. $1^{\circ}$ da Lei oㅡ 8.001, de 13 de março de 1990, que modificou a Lei no 7.990, de 28 de dezembro de 1989. Diário Oficial da União, 9 de janeiro de 1997. Disponível em: <http://www.planalto.gov.br/ccivil_03/leis/L9433.htm>. Acesso em: 08 de nov. de 2017.

CBH VELHAS. Comitê da Bacia Hidrográfica do rio Das Velhas - Deliberação Normativa do Comitê de Bacia Hidrográfica do rio das Velhas. Belo Horizonte, 2004. Disponível em: $<$ http://www.agbpeixevivo.org.br/images/2014/cbhvelhas/deliberacoes/DN 02-2004 criacao subcomites.pdf>. Acesso em: 02 de nov. de 2017.

DAVIDOFF, L. F. Introdução à psicologia. São Paulo: McGraw - Hill do Brasil, 1993.

IBGE. Censo Demográfico 2010. Características da População e dos Domicílios. Instituto Brasileiro de Geografia e Estatística, p. 48, 2010.

JACCOUD, M; MAYER, R. A observação direta e a pesquisa qualitativa. In: A pesquisa qualitativa Enfoques epistemológicos e metodológicos. Petrópolis: Vozes, 2008. p. 254-294.

LELO, T.; CAMINHAS L.R. Alfred Schütz e a comunicação: contribuições epistemológicas e conceituais para o estudo das interações. Revista Novos Olhares. v. 2 n. 2. p. 72-81, 2013. https://doi.org/10.11606/issn.2238-7714.no.2013.69829

LIEBMAN, M.; PAULSTON, R. G. Social Cartography: a new methodology for comparative studies. Compare: A Journal of Comparative and International Education, v. 24, n. 3, p.233-245, 1994. https://doi.org/10.1080/0305792940240304

MARIN, A. A. Pesquisa em educação ambiental e percepção ambiental. Pesquisa em Educação Ambiental, v. 3, n. 1, p. 203-222, 2008. https://doi.org/10.18675/2177-580X.vol3.n1.p203-222 
MERLEAU-PONTY, M. Fenomenologia da percepção. São Paulo: Martins Fontes, 1999.

MINAS GERAIS. Decreto 39.692. Institui o Comitê da Bacia Hidrográfica do rio das Velhas. Diário de Minas Gerais, 29 de junho de 1998. Disponível em:

$<$ https://www.almg.gov.br/consulte/legislacao/completa/completa.html?num=39692\&ano=1998\&tipo= DEC >. Acesso em: 28 de set. de 2017.

PAULSTON, R. G. Social Cartography: Mapping Ways of Seeing Social and Educational Change. New York: Garland Science, 1996.

SCBH ONÇA - SUBCOMITÊ DE BACIA HIDROGRÁFICA DO RIBEIRÃO DO ONÇA -. Plano de trabalho. Execução das obras e serviços para a revitalização de nascentes urbanas do Ribeirão Onça e divulgação de práticas ambientais para proteção e conservação das nascentes. Belo Horizonte, 2016. Disponível em: <http://cbhvelhas.org.br/images/projetos SCBH/projetos/PLANO_DE_TRABALHO_ONCA_FINAL_1.pdf >. Acesso em: 05 de nov. de 2017. SCBH ONÇA - SUBCOMITÊ DE BACIA HIDROGRÁFICA DO RIBEIRÃO DO ONÇA -. $2^{\circ}$ Relatório de acompanhamento de intervenções em nascentes urbanas. Belo Horizonte, 2017. Disponível em: <http://cbhvelhas.org.br/images/projetos

SCBH/projetos/Produto_5_II_Relatorio_de_Acompanhamento_de_Intervencao_em_Nascentes_Urba nas_alterado_FINAL.pdf $>$. Acesso em: 08 de nov. de 2017.

SEPÚLVEDA, R. DE O. Subcomitês como proposta de descentralização da gestão das águas na bacia do rio das Velhas : o Projeto Manuelzão como fomentador. Cadernos Manuelzão, p. 5-11, 2006.

SOBARZO, O. A Produção do Espaço Público: da Dominação à Apropriação. GEOUSP - Espaço e Tempo, n. 19, p. 93-111, 2006.

TELLIS, W. M. Application of a Case Study Methodology Application of a Case Study Methodology. The Qualitative Report, v. 3, n. 3, p. 1-19, 1997.

Recebido em: 28/09/2017

Aceito para publicação em: 26/04/2018 